\title{
Detection of isolated tumour cells in the blood and bone marrow of patients with gastric cancer by combined sorting, isolation and determination of MAGE-1, -2 mRNA expression
}

\author{
RAFAL SZATANEK $^{1}$, GRAZYNA DRABIK ${ }^{1}$, JAROSLAW BARAN ${ }^{1}$, PIOTR KOLODZIEJCZYK ${ }^{2}$, \\ JAN KULIG $^{2}$, JERZY STACHURA ${ }^{3}$ and MAREK ZEMBALA ${ }^{1}$
}

${ }^{1}$ Department of Clinical Immunology and Transplantation, ${ }^{2}$ First Department of General and Gastrointestinal Surgery and ${ }^{3}$ Department of Pathomorphology, Jagiellonian University Medical College, PL-30663 Cracow, Poland

Received October 23, 2007; Accepted December 21, 2007

\begin{abstract}
The detection of isolated (circulating or disseminated) tumour cells (ITC) in patients with cancer requires very sensitive methods, as such cells are very rare. In the present study, the method that combines the negative isolation of $\mathrm{CD} 45$ - leukocytes from the blood and bone marrow of patients with gastric cancer by flow cytometry, followed by the positive isolation of single cytokeratinpositive $\left(\mathrm{CK}^{+}\right)$cells by a Laser Capture Microdissection System for the determination of MAGE-1, -2 mRNA expression was used to detect ITC. This study shows that this method is highly sensitive as it allows to determine $\beta$-actinmRNA expression in a single $\mathrm{CK}^{+}$cell. Using $\geq 5 \mathrm{CK}^{+}$cells as a cut-off level, the MAGE-1 mRNA expression was detected in $100 \%$ of $\mathrm{CK}^{+}$cells in the peripheral blood and in $75 \%$ of bone marrow samples of patients with gastric cancer. The MAGE- 2 mRNA expression was observed in 40 and $58 \%$ of samples, respectively. Furthermore, an analysis of primary tumours and locoreginal lymph nodes with respect to the mRNA expression of the two genes showed that MAGE-1 mRNA expression was detected in $88 \%$ of the primary tumours and in $67 \%$ of the lymph node samples, whereas the MAGE-2 mRNA expression was observed in 72 and $67 \%$ of the cases, respectively. Thus, the method described here allows the precise and sensitive determination of tumour-associated gene expression in single ITC present in the blood and bone marrow of patients with gastric cancer.
\end{abstract}

Correspondence to: Dr Marek Zembala, Department of Clinical Immunology, Polish-American Institute of Paediatrics, Jagiellonian University Medical College, Wielicka St. 265, PL-30663 Cracow, Poland

E-mail: mizembal@cyf-kr.edu.pl

Key words: tumour cells, blood, bone marrow, MAGE-1, -2 mRNA, gastric cancer

\section{Introduction}

In many types of cancer, isolated (circulating or disseminated) tumour cells (ITC) in the blood and bone marrow are present (1-5). The detection frequency of these cells, in the blood and bone marrow, varies substantially not only in different types, but in the same type of cancer (6). Since these cells are very rare (app. 1 per $10^{5}$ to 1 per $10^{7}$ leukocytes), highly sensitive methods of detection are required.

There have been many attempts to develop techniques, which could be reliably used for the detection of ITC. These included immunocytochemistry with the use of antibodies for different tumour markers, although they are not tumourspecific (7). In conjunction with the antibody staining techniques, reverse transcriptase polymerase chain reaction (RT-PCR) was introduced as a powerful method for further analysis of potentially micrometastasizing tumour cells (8-12). This highly sensitive technique was designed for the detection of mRNA of presumptive tumour markers (13-17). Although this technique seemed ideal for detecting malignant cells, it frequently led to contradictory results to those obtained by immunocytochemistry. One of the many examples of tumour cell markers used are cytokeratins (CK), which are expressed by the epithelial, not necessarily malignant cells (18-22). The $\mathrm{CK}^{+}$cells are usually not present either in peripheral blood or bone marrow of normal subjects, though occasionally are detected (6). Data obtained by applying antibody staining and RT-PCR techniques showed contradictory results $(13,18)$. This contradiction questioned the method of choice, however, the results seemed promising. The main downfall of this approach has been the false positive results either in immunocytochemistry or RT-PCR. Although, the former may not be as sensitive as RT-PCR, the cellular source of the mRNA signal cannot be established without it. Furthermore, the false positive mRNA signals may derive from other (non-tumour) cells, e.g. PSA mRNA expressed by blood monocytes (23) or squamous cell carcinoma antigen and epidermal growth factor receptor mRNAs on activated lymphocytes which are present in some cancer patients (24), while false negative signals may arise from the diluting out of specific mRNA by coextracted RNA from other cells. 
With the introduction of the Laser Capture Microdissection System (LCM), a new possibility for ITC detection emerged. The LCM system, which is composed of a fluorescent microscope coupled with a laser module, enables the identification and selection of cells of interest by catapulting them out into a test tube lid with a laser impulse (25). By taking advantage of this system, we designed the method that concentrates, identifies $\mathrm{CK}^{+}$cells and allows their isolation for further analysis at the molecular level.

\section{Materials and methods}

Determination of MAGE-1 and MAGE-2 mRNA expression in tumour cell lines by real-time, nested PCR. Two tumour cell lines, HPC-4 (human pancreatic adenocarcinoma) and DeTa (colorectal adenocarcinoma) were used $(26,27)$. The cell lines were cultured by bi-weekly passages in RPMI-1640 medium with $5 \%$ foetal calf serum and $25 \mu \mathrm{g} / \mathrm{ml}$ gentamycin. All cell lines were regularly tested for Mycoplasma $s p$. contamination according to the procedure described by Ziegler-Heitbrock and Burger (28). The total RNA (tRNA) was extracted from $2 \times 10^{6}$ cells of each tumour cell line by the single-step isolation method using TRIZOL reagent (Invitrogen, Carlsbad, CA) according to the manufacturer's protocol. The first-strand cDNA was obtained from the tRNA samples $(2 \mu \mathrm{g})$ with M-MLV reverse transcriptase (Sigma, St. Louis, MO) and anchored oligo-dT (Sigma) primer as specified by the manufacturer's protocol. The cDNA was then used for nested PCR. For the first round of PCR, $20 \mu 1$ reactions, containing $5 \mu 1$ of cDNA, $2 \mu 1$ of 10X PCR buffer, $1.2 \mu 1$ of $25 \mathrm{mM}$ $\mathrm{MgCl}_{2}, 0.5 \mu \mathrm{M}$ of each of the outer MAGE-1 and MAGE-2 primer and 2 units of Taq DNA polymerase (Sigma) were run in a thermocycler (MJ Research, Watertown, MA). The following cycle profile was used: denaturation at $94^{\circ} \mathrm{C}$ for 6 min, annealing at $60^{\circ} \mathrm{C}$ for $30 \mathrm{sec}$ and extension at $72^{\circ} \mathrm{C}$ for 2 min for the first cycle; denaturation at $93^{\circ} \mathrm{C}$ for $40 \mathrm{sec}$, annealing at $60^{\circ} \mathrm{C}$ for $30 \mathrm{sec}$ and extension at $72^{\circ} \mathrm{C}$ for $20 \mathrm{sec}$ for 14 cycles; denaturation at $93^{\circ} \mathrm{C}$ for $40 \mathrm{sec}$, annealing at $60^{\circ} \mathrm{C}$ for $30 \mathrm{sec}$ and extension at $72^{\circ} \mathrm{C}$ for $30 \mathrm{sec}$ for 50 cycles; final extension at $72^{\circ} \mathrm{C}$ for $2 \mathrm{~min}$. The outer and inner primer pairs for MAGE-1 and MAGE-2 are listed in Table I. For the second round of PCR, $5 \mu 1$ of each sample from the first reaction was transferred into glass capillaries, where real-time PCR, with the inner primer pair for MAGE-1 and MAGE-2, was performed using the LightCycler thermocycler (Roche Diagnostics, Mannheim, Germany). The $10 \mu 1$ reaction mix for each sample composed of $0.5 \mu \mathrm{M}$ of each of the inner primer, $1.6 \mu \mathrm{l}$ of $25 \mathrm{mM} \mathrm{MgCl}$ and $1 \mu \mathrm{l}$ of FastStart DNA SYBR-Green I Reaction Mix (Roche Diagnostics). The

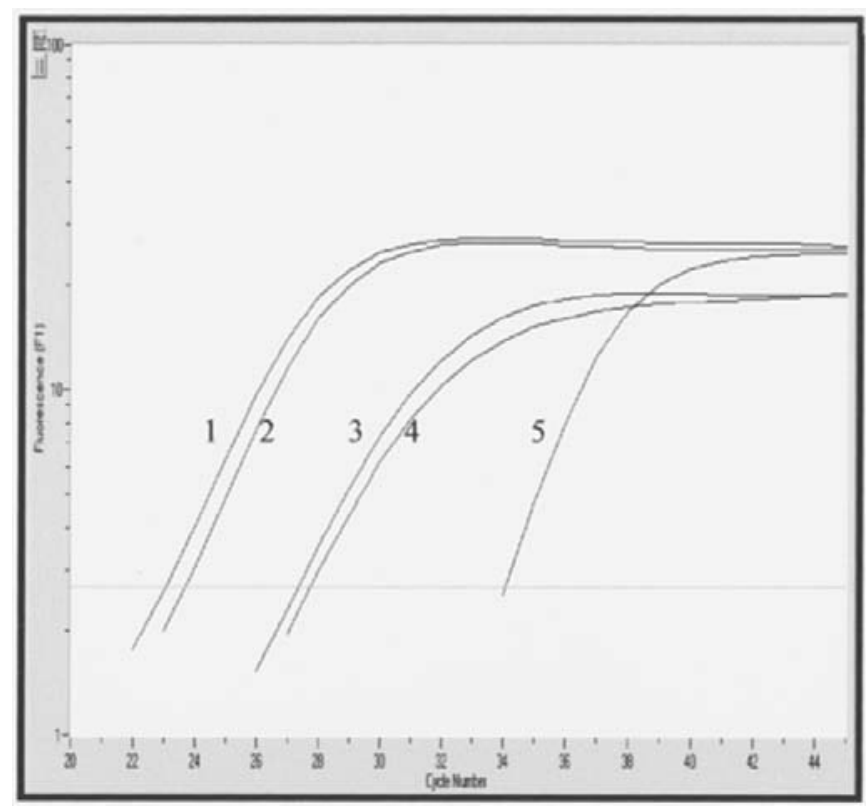

Figure 1. MAGE-1 and MAGE-2 mRNA expression in two tumour cell lines by real-time, nested PCR. 1, MAGE-1 (HPC-4); 2, MAGE-1 (DeTa); 3, MAGE-2 (HPC-4); 4, MAGE-2 (DeTa); 5, negative control.

cycle profile for this PCR run was as follows: initial denaturation at $94^{\circ} \mathrm{C}$ for $10 \mathrm{~min}$, then denaturation at $93^{\circ} \mathrm{C}$ for $40 \mathrm{sec}$, annealing at $58^{\circ} \mathrm{C}$ for $30 \mathrm{sec}$ and elongation at $72^{\circ} \mathrm{C}$ for $30 \mathrm{sec}$ for $30 \mathrm{cycles}$, followed by the final extension at $72^{\circ} \mathrm{C}$ for $2 \mathrm{~min}$. To verify the amplified product, a melting curve analysis using LightCycler software was performed for each sample. As a negative control, the human urothelial cell line (HCV-29) was used.

Determination of the $\beta$-actin $m R N A$ threshold by real-time $P C R$. Different numbers of HPC-4 tumour cells, from 1 to 500,000 , were sorted by flow cytometry (FACS Vantage SE, BD Biosciences Immunocytometry Systems, San Jose, CA) into separate test tubes. The PALM RNA isolation kit (P.A.L.M., Bernried, Germany), designed for tRNA isolation from a small number of cells, was used for the extraction of tRNA. The obtained cDNA was then used in a real-time PCR reaction for the mRNA detection of the housekeeping gene, $\beta$-actin, using the above protocol. The $\beta$-actin primer sequences were as follows: sense 5'-GGATGCAGAAGGA GATCACTG-3', antisense 5'-CGATCCACACGGAGTAC TTG-3'. The cycle profile for the $\beta$-actin real-time PCR run was as follows: initial denaturation at $94^{\circ} \mathrm{C}$ for $10 \mathrm{~min}$, then denaturation at $95^{\circ} \mathrm{C}$ for $10 \mathrm{sec}$, followed by annealing at

Table I. The primer sequences for MAGE-1 and MAGE-2.

\begin{tabular}{lll} 
Outer sense & 5'-GTA-GAG-TTC-GGC-CGA-AGG-AAC-3' & 5'-CAT-TGA-AGG-AGA-AGA-TCT-GCC-T-3'; \\
Outer antisense & 5'-CAG-GAG-CTG-GGC-AAT-GAA-GAC-3' & 5'-GAG-TAG-AAG-AGG-AAG-AAG-CGG-T-3' \\
Inner sense & 5'-TAG-AGT-TCG-GCC-GAA-GGA-AC-3' & 5'-CAT-TGA-AGG-AGA-AGA-TCT-GCC-T-3' \\
Inner antisense & 5'-CTG-GGC-AAT-GAA-GAC-CCA-CA-3' & 5'-CAG-GCT-TGC-AGT-GCT-GAC-TC-3' \\
\hline
\end{tabular}




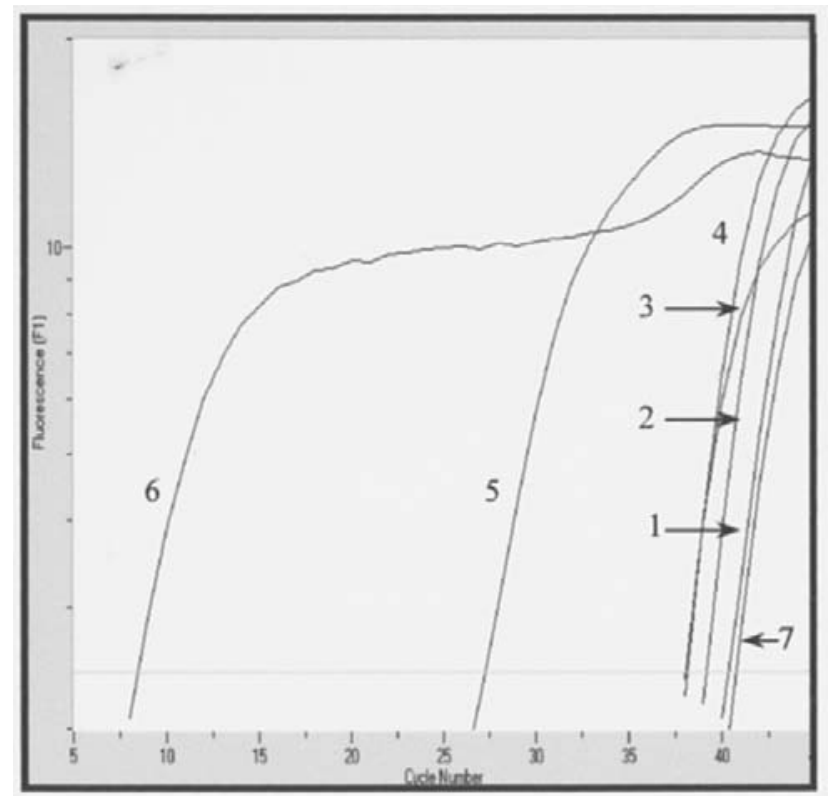

Figure 2. $\beta$-actin mRNA expression in sorted HPC-4 cancer cells. 1, 1 cell; 2, 10 cells; 3 , 100 cells; 4, 1000 cells; 5, 100,000 cells; 6, 500,000 cells; 7, negative control.

$64^{\circ} \mathrm{C}$ for 40 cycles. A melting curve analysis was performed for each sample.

Expression of MAGE-1, -2 mRNA in tumour (HPC-4) cells admixed to normal blood. In a pilot study, HPC-4 tumour cells were added to the blood from healthy donors in the proportion of 1 per $1 \times 10^{5}$ leukocytes. Erythrocytes were lysed with BD FACS Lysing Solution (BD Biosciences, San Jose, CA) and leukocytes were washed with ice-cold PBS. The smears of cells on PEN membrane-covered microscope slides (P.A.L.M.) were fixed with $80 \%$ ethanol for $1 \mathrm{~min}$, as previously described (25). Cells were stained with phycoerythrin (PE) conjugated anti-cytokeratin (A45/BB3) monoclonal antibody (mAb, Micromet, Munich, Germany), which detects common epitopes of cytokeratin 8, 18 and 19. The slides were then analysed under the IX71 inverted fluorescent microscope (Olympus, Tokyo, Japan) and $1,5,10,20$ and $100 \mathrm{CK}^{+}$cells were laser cut and catapulted out into separate test tube lids by using the LCM System (P.A.L.M.). Then, tRNA was isolated from these cells using the highly-sensitive PALM RNA isolation kit.

MAGE-1, -2 mRNA expression in the primary tumour and locoreginal lymph nodes of patients with gastric cancer. Snap-frozen microtome sections of the primary tumours $(\mathrm{n}=32)$ and lymph nodes $(\mathrm{n}=27)$ from the resection specimens of gastric cancer were placed on the PEN membrane-covered microscope slides (P.A.L.M.). The slides were then stained with hematoxylin-eosin to determine the presence of cancer cells under a light microscope based on their morphology and 50 to 100 from parallel slides were laser cut and isolated using the LCM system. Then, tRNA was isolated and MAGE-1, -2 mRNA expression was examined in the same manner as described above.

MAGE-1, -2 mRNA expression in $\mathrm{CK}^{+}$cells isolated from the peripheral blood and bone marrow of patients with gastric cancer. The whole blood and bone marrow samples from patients with gastric cancer were lysed with BD FACS Lysing Solution, washed in ice-cold PBS, then labelled with PE conjugated anti-CD45 mAb (Dako, Glostrup, Denmark) and negatively sorted for CD45- cells by flow cytometry (FACS Vantage) as previously described (29). The smears of CD45 cell population on PEN membrane-covered microscope slides (P.A.L.M.) were then fixed with $80 \%$ ethanol and incubated with PE-labelled A45/B-B3 mAb. At least $5 \mathrm{CK}^{+}$cells were isolated using the LCM system and tRNA was isolated. The $\mathrm{RT}$ reaction was performed as described above, though instead of M-MLV, the Enhanced M-MLV reverse transcriptase (Sigma) was used. The synthesized cDNA was then used in real-time, nested PCR to check MAGE-1, -2 mRNA expression using the same protocol as described above.

\section{Results}

Determination of MAGE-1 and MAGE-2 mRNA expression in tumour cell lines by real-time, nested PCR. Initial experiments indicated that the tumour cell lines, HPC-4 and DeTa, expressed similar amounts of mRNA for MAGE-1 and -2 (Fig. 1). Furthermore, no mRNA expression was observed for either gene in the non-malignant cell line, HCV-29 (data not shown). In order to establish the sensitivity of $\beta$-actin mRNA detection, different numbers of HPC-4 cells were used for real-time PCR. The data suggested that the mRNA detection threshold was a single cell, from which a positive real-time PCR signal was obtained (Fig. 2). An increase in the number of cells was proportional to the increase in the mRNA B-actin expression. A melting curve analysis using the LightCycler software showed that the signals were obtained from the actual products and not primer dimers (data not shown).

MAGE-1, -2 mRNA expression in the HPC-4 cells isolated from the peripheral blood using the Laser Capture Microdissection System (LCM). In the model studies, HPC-4 cells were admixed to the blood from normal donors, stained with

Table II. mRNA expression of MAGE-1 and MAGE-2 in primary tumour and lymph node samples of patients with gastric cancer.

\begin{tabular}{lcccc}
\hline mRNA & \multicolumn{2}{c}{ Primary tumour $(\mathrm{n}=32)$} & \multicolumn{2}{c}{ Lymph nodes $(\mathrm{n}=27)$} \\
\cline { 2 - 4 } & Number of positive & $\%$ & Number of positive & 67 \\
\hline MAGE-1 & 28 & 88 & 18 & 67 \\
\hline
\end{tabular}


A

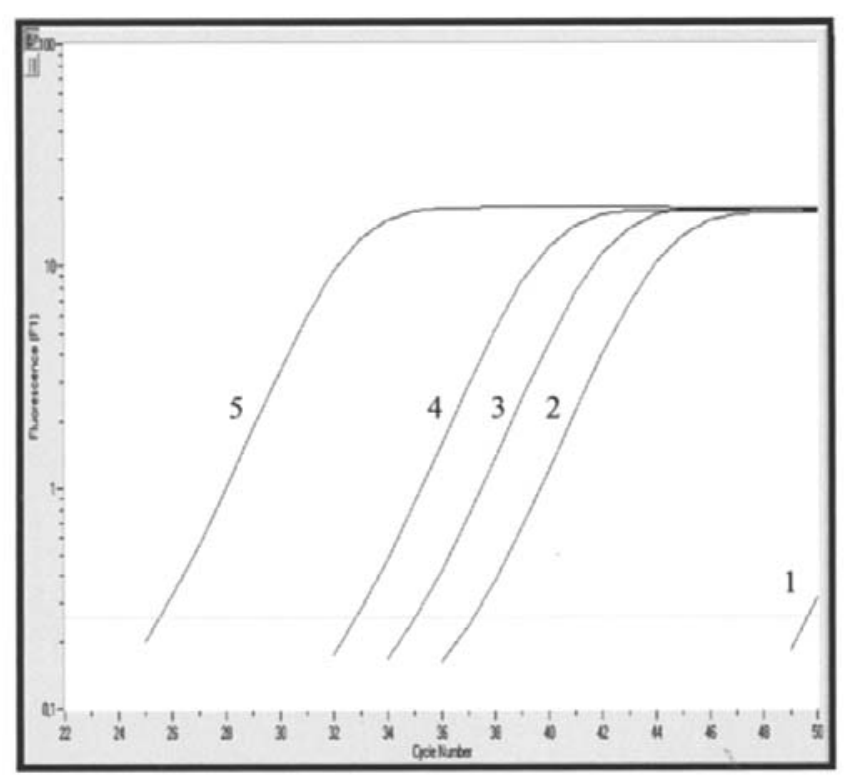

B

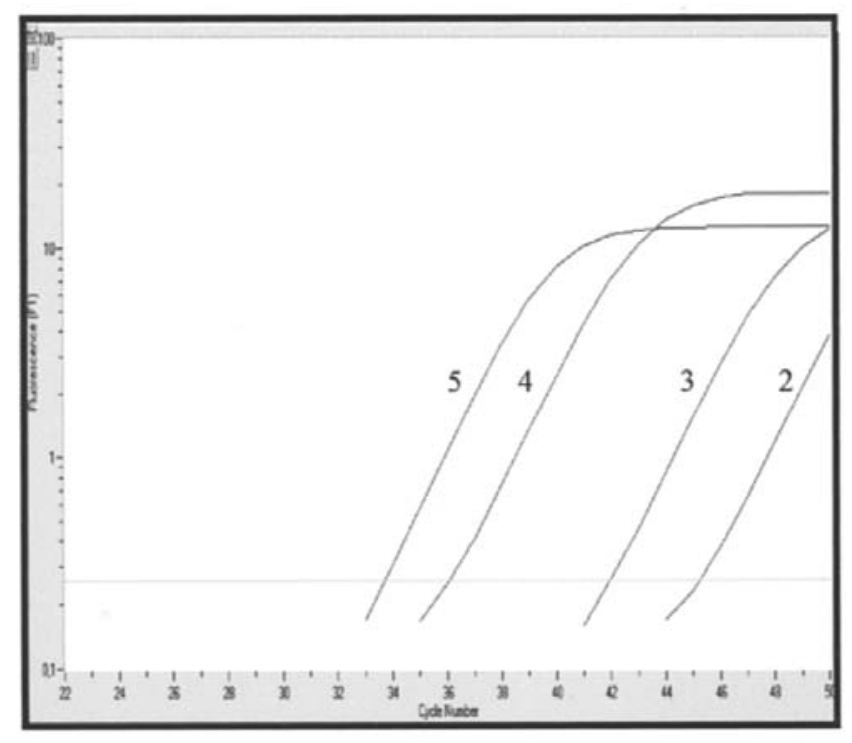

Figure 3. (A) mRNA expression for MAGE-1 in HPC-4 cells isolated from the blood cells as detected by real-time PCR (LightCycler). 1, 1 cell; 2, 5 cells; 3, 10 cells; 4, 20 cells; 5, 100 cells; 6, negative control (out of range). (B) mRNA expression for MAGE-2 in HPC-4 cells isolated from the blood cells as detected by real-time PCR (LightCycler). 1, 1 cell (out of range); 2, 5 cells; 3 , 10 cells; 4, 20 cells; 5, 100 cells; 6, negative control (out of range).
PE-labelled anti-CK mAb, and then 1, 5, 10, 20 and 100 $\mathrm{CK}^{+}$cells were isolated using the LCM system. Preliminary experiments showed that ethanol fixing and PEN membranecovered microscope slides substantially reduced the mRNA loss in comparison to standard microscope slides and formalin fixation. Additionally, ethanol fixation was shorter, did not alter the cell morphology and had no negative effect on the CK-staining. Therefore, it was chosen for further studies. Membrane-covered microscope slides enabled to cut around chosen cells and catapult them out intact into the test tube lid. Furthermore, in order to increase the sensitivity of the RT reaction, the Enhanced M-MLV reverse transcriptase was used. The mRNA expression for MAGE-1 and -2 was detected (Fig. 3A and B). The sample where tRNA was isolated from 100 HPC-4 cells showed the strongest mRNA signal for both of the tested genes, however, a positive signal was already detected in the sample containing five HPC-4 cells.

MAGE-1, -2 mRNA expression in the primary tumour and locoreginal lymph nodes of gastric cancer patients. Cancer cells were isolated from resected primary tumour specimens $(n=32)$ and locoregional lymph nodes $(n=27)$. Expression of MAGE-1 mRNA in primary tumour samples was observed in $28(88 \%)$ and MAGE-2 in $23(72 \%)$ cases (Table II). The respective positive cases of the lymph node samples for MAGE-1 and MAGE-2 were 18 (67\%) (Table II).

MAGE-1, -2 mRNA expression in $\mathrm{CK}^{+}$cells isolated from the peripheral blood/bone marrow samples from patients with gastric cancer. The $\mathrm{CK}^{+}$cells were identified in 17 smears of CD45- cells isolated from 5 peripheral blood and 12 bone marrow samples. Table III shows that 5 out of 5 (100\%) cases, where $\mathrm{CK}^{+}$cells were isolated by LCM from peripheral blood, expressed mRNA for MAGE-1. The mRNA coexpression for MAGE-2 was detected twice (40\%). In the bone marrow (Table III), MAGE-1 mRNA was observed in 9 out of 12 (75\%) cases and MAGE-2 mRNA in 7 samples $(58 \%)$. Transcription of the two genes occurred in 5 cases (42\%). In two cases $(17 \%)$ mRNA for MAGE-2 only was detected. Altogether, 16 out of $17 \mathrm{CK}^{+}$samples showed positive expression for either gene.

\section{Discussion}

Our previous studies indicated that the application of FACS sorting of CD45 cells increases the sensitivity of detection of ITC as defined by the presence of CK (29). Since not all circulating $\mathrm{CK}^{+}$cells are necessarily tumour cells, the present study was undertaken to prove that these cells are most likely

Table III. Expression of MAGE-1 and MAGE-2 mRNA in $\mathrm{CK}^{+}$cells isolated from peripheral blood and bone marrow samples of patients with gastric cancer.

\begin{tabular}{lcccc}
\hline mRNA & \multicolumn{2}{c}{ Peripheral blood $(\mathrm{n}=5)$} & & \multicolumn{2}{c}{ Bone marrow $(\mathrm{n}=12)$} \\
\cline { 2 - 5 } & Number of positive & $\%$ & Number of positive & 75 \\
\hline MAGE-1 & 5 & 100 & 9 & 58 \\
MAGE-2 & 2 & 40 & 7 & 58 \\
\hline
\end{tabular}


cancer cells as judged by the isolation of single $\mathrm{CK}^{+}$cells and determination of MAGE-1, -2 mRNA in them. This also allows the determination of the cellular source of tumour markermRNA, as false positive mRNA signals may be a problem in the evaluation of ITC detection in cancer patients (6). Up to now, the procedures using RT-PCR for the detection of disseminated tumour cells were based on tRNA isolation from the whole blood or bone marrow samples $(4,5,11,19)$. The false positive signals may be due to the illegitimate transcription of several tumour-associated or epithelial-specific genes, which was observed in the haematopoietic cells in the bone marrow of a control subject group (30). On the other hand, RNA from normal cells can dilute out the actual mRNA signal specific for the tumour cells, thus leading to false negative results (14).

We also observed the presence of MAGE-1, -2 mRNA in plasma of some gastric cancer patients (unpublished observation), which is likely associated with circulating tumour-derived microvesicles (31). Here, through the application of three different techniques, we have established the protocol that is designed for the specific selection of single tumour cells in order to study the expression of tumour-associated genes in them. This technique included sorting out of $\mathrm{CD}^{4} 5^{+}$cells from the blood/bone marrow, isolation of single $\mathrm{CK}^{+}$cells from the $\mathrm{CD} 45^{-}$ population by LCM, the extraction of tRNA from them, RT and nested, real-time PCR. The data suggest that this technique is highly sensitive since in the model study we were able to obtain the mRNA signal for $\beta$-actin from a single cell. However, it should be pointed out, that the single-cell mRNA signal detected was of a housekeepinggene origin. These types of genes are constitutively expressed in a cell, which makes their mRNAs more 'abundant' in a cell as compared to the inducible genes. In the case of the MAGE-1,-2 mRNA expression, which is inducible, a positive signal was detected in tRNA isolated from five HPC-4 cells, which set up the detection threshold for further studies.

As previously reported, disseminated gastrointestinal cancer cells do not express the CD45 molecule (29). Using anti-CD45 mAb and flow cytometry, we have negatively sorted out CD45- cell population from the peripheral blood/bone marrow samples of patients with gastric cancer. This negative sorting enabled us to remove all leukocytes $\left(\mathrm{CD} 45^{+}\right)$, that allowed enrichment of the presumptive tumour cells. In the model study, cancer (HPC-4) cells admixed to normal blood were used for the determination of specificity and sensitivity of the method. Following lysis of erythrocytes, the cells were ethanol-fixed on PEN membrane-covered microscope slides and were stained with anti-CK mAb. It was found that ethanol fixing is much more efficient as compared to formalin fixing, which is in keepings with the results obtained by others (25). Ethanol fixing is a much shorter procedure, which reduces the sample exposure time to ribonucleases, thus preventing mRNA loss. Furthermore, the cells were undamaged, as seen under the fluorescent microscope and the fixing did not have any negative effects on anti-CK mAb staining. To further prevent the mRNA loss, membrane-covered microscope slides were used. LCM isolation of the selected cells from the standard microscope slides requires a much stronger laser impulse causing the destruction of the cell structure, which may result in mRNA loss.

To ascertain that MAGE-1, -2 mRNA in ITC was derived from cancer cells, RNA was isolated from primary tumours and locoreginal lymph nodes. The mRNA for MAGE-1 and MAGE-2 was observed in the majority (88 and $72 \%$, respectively) of gastric cancer samples. This is in accordance with other observations indicating the expression of MAGE-1, -2 mRNA in 40\% and MAGE-1 in 59.9\% of the gastric cancer specimens $(32,33)$. The higher rate of detection found in this study may be due to the use of isolated cancer cells as a source of RNA. In the case of the lymph nodes, $67 \%$ samples expressed mRNA for the two of the genes.

The CK staining is commonly used for the detection of ITC $(7,21)$. Out of the $17 \mathrm{CK}^{+}$samples (peripheral blood and bone marrow samples), $94.1 \%$ showed the mRNA expression for either MAGE-1 or -2 , or both pointing to the fact that these cells are indeed cancer cells and that this method is highly sensitive. It should be noted that the total number of the viewed CD45- specimens was over 300 , which only confirms that finding a potential tumour cell is very difficult and elusive.

The data suggest that the designed method used for selection and identification of ITC is highly sensitive. Its main attribute is the concentration of potential tumour cells (by elimination of blood and haematopoietic CD45 ${ }^{+}$cells) into a small sample volume, which can be easily transferred onto a microscope slide and stained for tumour markers. The LCM system enables to identify and catapult a cell of interest for other downstream molecular studies. This feature, coupled with a highly sensitive real-time nested PCR, further helps to identify a tumour cell with an even higher probability, though the deficient expression of the marker gene in micrometastatic tumour cells (30) remains a problem. It should be kept in mind, that the detection of molecular tumour markers alone without the proper identification of their cellular origin may not necessarily indicate their malignant nature as several tumour-associated antigens may be expressed by activated lymphocytes (24). Thus, enrichment, identification and isolation of $\mathrm{CK}^{+}$cells and the determination of tumourassociated gene expression makes this method more reliable than the use of molecular methods alone applied to the whole blood or bone marrow samples.

\section{Acknowledgements}

This study received financial support from the State Committee for Scientific Research (grant no. KBN-091/ PO5/2003). We wish to thank Ms. I. Ruggiero for her skillful technical assistance.

\section{References}

1. Benoy IH, Elst H, Philips M, Wuyts H, Van Dam P, Scharpe S, Van Marck E, Vermeulen PB and Dirix LY: Real-time RT-PCR detection of disseminated tumour cells in bone marrow has superior prognostic significance in comparison with circulating tumour cells in patients with breast cancer. Br J Cancer 94: 672-680, 2006. 
2. Guadagni F, Kantor J, Aloe S, Carone MD, Spila A, D'Alessandro R, Abbolito MR, Cosimelli M, Graziano F, Carboni F, Carlini S, Perri P, Sciarretta F, Greiner JW, Kashmiri SV, Steinberg SM, Roselli M and Schlom J: Detection of blood-borne cells in colorectal cancer patients by nested reverse transcription-polymerase chain reaction for carcinoembryonic antigen messenger RNA: longitudinal analyses and demonstration of its potential importance as an adjunct to multiple serum markers. Cancer Res 61: 2523-2532, 2001.

3. Hermanek P, Hutter RV, Sobin LH and Wittekind C: International Union Against Cancer. Classification of isolated tumor cells and micrometastasis. Cancer 86: 2668-2673, 1999.

4. Ikeguchi M and Kaibara N: Detection of circulating cancer cells after a gastrectomy for gastric cancer. Surg Today 35: 436-441, 2005.

5. Katsumata K, Sumi T, Mori Y, Hisada M, Tsuchida A and Aoki T: Detection and evaluation of epithelial cells in the blood of colon cancer patients using RT-PCR. Int J Clin Oncol 11: 385-389, 2006.

6. Vogel I and Kalthoff H: Disseminated tumour cells. Their detection and significance for prognosis of gastrointestinal and pancreatic carcinomas. Virchows Arch 439: 109-117, 2001.

7. Oyama K, Terashima M, Takagane A and Maesawa C: Prognostic significance of peritoneal minimal residual disease in gastric cancer detected by reverse transcription-polymerase chain reaction. Br J Surg 91: 435-443, 2004.

8. Mataki Y, Takao S, Maemura K, Mori S, Shinchi H, Natsugoe S and Aikou T: Carcinoembryonic antigen messenger RNA expression using nested reverse transcription-PCR in the peripheral blood during follow-up period of patients who underwent curative surgery for biliary-pancreatic cancer: longitudinal analyses. Clin Cancer Res 10: 3807-3814, 2004.

9. Rosenberg R, Hoos A, Mueller J, Baier P, Stricker D, Werner M, Nekarda H and Siewert JR: Prognostic significance of cytokeratin-20 reverse transcriptase polymerase chain reaction in lymph nodes of node-negative colorectal cancer patients. J Clin Oncol 20: 1049-1055, 2002.

10. Sadahiro S, Suzuki T, Tokunaga N, Yurimoto S, Yasuda S, Tajima T, Makuuchi H, Murayama C and Matsuda K: Detection of tumour cells in the portal and peripheral blood of patients with colorectal carcinoma using competitive reverse transcriptasepolymerase chain reaction. Cancer 92: 1251-1258, 2001.

11. Taniguchi T, Makino M, Suzuki K and Kaibara N: Prognostic significance of reverse transcriptase-polymerase chain reaction measurement of carcinoembryonic antigen mRNA levels in tumour drainage blood and peripheral blood of patients with colorectal carcinoma. Cancer 89: 970-976, 2000

12. Wang JY, Wu CH, Lu CY, Hsieh JS, Wu DC, Huang SY and Lin SR: Molecular detection of circulating tumour cells in the peripheral blood of patients with colorectal cancer using RTPCR: significance of the prediction of postoperative metastasis. World J Surg 30: 1007-1013, 2006.

13. Ge MJ, Wu QC, Wang M, Zhang YH and Li LB: Detection of disseminated lung cancer cells in regional lymph nodes by assay of CK19 reverse transcriptase polymerase chain reaction and its clinical significance. J Cancer Res Clin Oncol 131: 662-668, 2005.

14. Guo J, Xiao B, Zhang X, Jin Z, Chen J, Qin L, Mao X, Shen G, Chen $\mathrm{H}$ and Liu $\mathrm{Z}$ : Combined use of positive and negative immunomagnetic isolation followed by real-time RT-PCR for detection of the circulating tumour cells in patients with colorectal cancers. J Mol Med 82: 768-774, 2004.

15. Kufer P, Zippelius A, Lutterbuse R, Mecklenburg I, Enzmann T, Montag A, Weckermann D, Passlick B, Prang N, Reichardt P, Dugas M, Kollermann M, Pantel K and Riethmuller G: Heterogeneous expression of $M A G E-A$ genes in occult disseminated tumour cells: a novel multimarker reverse transcription-polymerase chain reaction for diagnosis of micrometastatic disease. Cancer Res 62: 251-261, 2002.

16. Lledo SM, Garcia-Granero E, Dasi F, Ripoli R, Garcia SA, Cervantes A and Alino SF: Real-time quantification in plasma of human telomerase reverse transcriptase (hTERT) mRNA in patients with colorectal cancer. Colorectal Dis 6: 236-242, 2004.

17. Nosotti M, Falleni M, Palleschi A, Pellegrini C, Alessi F, Bosari S and Santambrogio L: Quantitative real-time polymerase chain reaction detection of lymph node lung cancer micrometastasis using carcinoembryonic antigen marker. Chest 128: 1539-1544, 2005 .
18. Saintigny P, Coulon S, Kambouchner M, Ricci S, Martinot E, Danel C, Breau J and Bernaudin J: Real-time RT-PCR detection of CK19, CK7 and MUC1 mRNA for diagnosis of lymph node micrometastases in non small cell lung carcinoma. Int J Cancer 115: 777-782, 2005 .

19. Schuster R, Max N, Mann B, Heufelder K, Thilo F, Grone J, Rokos F, Buhr HJ, Thiel E and Keilholz U: Quantitative real-time RT-PCR for detection of disseminated tumour cells in peripheral blood of patients with colorectal cancer using different mRNA markers. Int J Cancer 108: 219-227, 2004.

20. Stathopoulou A, Vlachonikolis I, Mavroudis D, Perraki M, Kouroussis CH, Apostolaki S, Malamos N, Kakolyris S, Kotsakis A, Xenidis N, Reppa D and Georgoulias V: Molecular detection of cytokeratin-19-positive cells in the peripheral blood of patients with operable breast cancer: evaluation of their prognostic significance. J Clin Oncol 20: 3404-3412, 2002.

21. Gretschel S, Schick C, Schneider U, Estevez-Schwarz L, Bembenek A and Schlag P: Prognostic value of cytokeratinpositive bone marrow cells of gastric cancer patients. Ann Surg Oncol 14: 373-380, 2007

22. Tsavellas G, Huang A, McCullough T, Patel H, Araia R and Allen-Mersh TG: Flow cytometry correlates with RT-PCR for detection of spiked but not circulating colorectal cancer cells. Clin Exp Metastasis 19: 495-502, 2002.

23. Fadlon EJ, Rees RC, McIntyre C, Sharrard RM, Lawry J and Hamdy FC: Detection of circulating prostate-specific antigenpositive cells in patients with prostate cancer by flow cytometry and reverse transcription polymerase chain reaction. Br J Cancer 74: 400-405, 1996.

24. Kowalewska M, Chechlinska M, Markowicz S, Kober P and Nowak R: The relevance of RT-PCR detection of disseminated tumour cells is hampered by the expression of markers regarded as tumour-specific in activated lymphocytes. Eur J Cancer 42: 2671-2674, 2006

25. Bi WL, Keller-McGandy C, Standaert DG and Augood SJ: Identification of nirtic oxide synthase neurons for laser capture microdissection and mRNA quantification. BioTechniques 33: 1274-1283, 2002.

26. Mytar B, Siedlar M, Woloszyn M, Colizzi V and Zembala M: Cross-talk between human monocytes and cancer cells during reactive oxygen intermediates generation: the essential role of hyaluronan. Int J Cancer 94: 727-732, 2001.

27. Siedlar M, Stachura J, Szczepanik A, Popiela T, Mattei M, Vendetti S, Colizzi V and Zembala M: Characterization of human pancreatic carcinoma cell line with high metastatic potential in SCID mice. Invasion Metastasis 15: 60-69, 1995.

28. Ziegler-Heitbrock HWL and Burger R: Rapid removal of Mycoplasma from cell lines mediated by a direct effect of complement. Exp Cell Res 173: 388-392, 1987.

29. Baran J, Pituch-Noworolska A, Krzeszowiak A, Wieckiewicz J, Stachura J, Pryjma J, Popiela T, Szczepanik A and Zembala M: Detection of cancer cells in the blood by FACS sorting of CD45cells. Int J Mol Med 1: 525-533, 1998.

30. Zippelius A, Kufer P, Honold G, Kollermann MW, Oberneder R, Schlimok G, Riethmuller G and Pantel K: Limitations of reverse-transcriptase polymerase chain reaction analyses for detection of micrometastatic epithelial cancer cells in bone marrow. J Clin Oncol 15: 2701-2708, 1997.

31. Baj-Krzyworzeka M, Szatanek R, Weglarczyk K, Baran J, Urbanowicz B, Branski P, Ratajczak MZ and Zembala M: Tumour-derived microvesicles carry several surface determinants and mRNA of tumour cells and transfer some of these determinants to monocytes. Cancer Immunol Immunother 55: 808-818, 2006.

32. Inoue H, Mori M, Honda M, Li J, Shibuta K, Mimori K, Ueo H and Akiyoshi T: The expression of tumor-rejection antigen 'MAGE' genes in human gastric carcinoma. Gastroenterology 109: 1522-1525, 1995.

33. Kim KH, Choi JS, Kim IJ, Ku JL and Park JG: Promoter hypomethylation and reactivation of MAGE-A1 and MAGE-A3 genes in colorectal cancer cell lines and cancer tissues. World J Gastroenterol 12: 5651-5657, 2006. 